\title{
Digitalization of Financial Services in Albania Under Restricted Measures Covid-19
}

\author{
Rezana Balla \\ PhD, Marin Barleti University
}

\section{Abstract}

Under the restricted measures due to the global pandemic Covid-19, like all other services, financial services had difficulties in performing their financial activities. These difficulties are stronger at countries where financial services are denied for a long time. Financial services denial is an issue that has affected not only Albania but small Balkan countries as well. The reasons for this denial are many, but among them we can distinguish the lack of credit experience, as one of the common reasons to be excluded in these countries from the development of the financial sector. Currently, one of the reasons for the financial denial is the emergency created by Covid-19, where physical distancing and other measures taken by governments to restrict movement and services make financial service impossible. Thus, one of the most effective ways to perform financial services remotely is financial technology. Financial technology refers to the possibilities of financial innovation through technology that can result in new business models, applications, processes, or products with an effectiveness related to financial markets and institutions and the provision of financial services. This paper aims to present the challenges of the legal framework and regulatory institutions, to provide recommendations for its improvement, to enable the development of financial technology in the financial market in Albania. The paper address issues such as the Bank of Albania's consideration on the Directive ${ }^{1}$ (EU) 2015/2366 On Payment Services (PSD II). What benefits or challenges would its implementation bring? How is the financial industry projected after the implementation of PSD II? What are the biggest job challenges with payment institutions that have not been to the market before or that bring technology innovations? The paper addresses the issue of money laundering through online digital transactions as well.

Keywords: financial teknology, digital financial services, online process, know your client, physical presence

\footnotetext{
1 Directive (EU) 2015/2366 On Payment Services (PSD II) published at European Official Journal entered into force on January 2018, https://eur-lex.europa.eu/legalcontent/EN/LSU/?uri=CELEX:32015L2366 visited on 01.06.2020.
} 


\section{Introduction}

Almost all small Balkan countries, mainly those that were part of the former communist alliance, have no credit history, they have been excluded from financial and banking services, due to the policies of communist totalitarian regimes which did not allow lending, as it constituted a capitalist phenomenon. Although the banking market has developed in Albania, in these last years of transition period, large part of Albanian citizens has not been able to benefit from banking services, for many reasons. One of the major issues of the financial markets in Albania remains the financial education of consumers. Albanian citizens have very little knowledge 1 about banking and financial products, in general. For many of the interviewees, it is stated that the bank accounts have been opened by the businesses in which they were employed, as they did not need to open and use the bank account and benefit from the banking services. The issue of financial education is included and is part of all the strategies of the supervisory authorities and the actors and factors of the financial market. Education should be part of school curricula so that citizens are familiar with financial products, understand them and then use them to the best of their capability. The paradox of not benefiting from bank financial services is the lack of credit history, if someone does not have a credit history, cannot benefit from bank financial services. At least that was true until a short time ago. Microfinance institutions in Albania aim to reach their customers by enabling them to provide services such as lending through electronic devices. So, they aim to provide online financial services to their customers. The online process has great benefits for financial institutions. Thus, the number of transactions through electronic means of communication, various smart phone devices has been increased. Through, the use of the online process will be ensured higher efficiency and productivity. Consumption and competition and the democratization of financial services are increasing. The online process is the easiest and fastest choice for the consumer. Additionally, through the online process, the prevention of money laundering2 is ensured, as every step and transaction performed remains preserved and documented. At the same time, the online process can contribute more to increasing transparency to customers and regulatory institutions. Selecting the use of the online process can lead to the involvement or exclusion of customers from this process. One of the best ways to increase customer engagement in choosing digital finance is to raise awareness and sensitize them to this selection. Financial education should mainly aim at involving customers from rural areas, as their difficulties in accessing financial services are even greater.

Increasing the use of financial technology will lead to the processing of sensitive personal data. Because, online processes will require the processing of personal

\footnotetext{
1 The data were published by the Albanian Microfinance Association based on a study conducted by the organization IDRA from the findings it results that $49 \%$ of respondents have average or little knowledge in terms of financial education. Published at Bankieri Magazine, no.26, Tirana, April 2020. 2 Shegan, A. (2010), La lutte contre le terrorisme: étude de droit comparé (droit français, droit albanais) et de droit pénal international, Tirane, Albania. p. 237
} 
biometric data1 for distance identification. The use of online data processing and the benefit of digital financial services will contribute to bringing innovation to the financial market and create the first steps towards the digitalization of financial services by contributing to increasing the number of individuals using bank accounts today in the country. In this way, digital financial services will also contribute to the formalization of the economy, knowing that a part of the market economy in Albania is still informal.

\section{Legal and Institutional Challenges in Albania}

\section{II.1- Amendments of Anti- Money Laundering Law}

In these times of global pandemic, the selection of digital finance to access financial services is a necessity requirement. In the context of the development and digitalization of financial services, the aim is to carry out the process of remote identification of financial institutions' customers. This fact constitutes one of the fundamental issues regarding the prevention of money laundering. Actually, there is a legal framework and lots of laws and regulations that are implicated in the performance of digital financial services. We can even say that this will affect the institutional and practical behavior in Albania. So far, no non-bank financial institution, but even the banks themselves in Albania, do not perform a full online financial service without the physical presence of the client. The banks perform online financial services only after the clients have appeared at the bank and they have performed the procedure of recognizing and identifying the client.

Undoubtedly, the most important role in this context is played by the Directorate of Prevention and Money Laundering (DPML). Improvements of the Law on Prevention of Money Laundering2 in June $2019^{3}$ poses a new challenge for DPML. Because, for the first time in the history of this law, it is foreseen the performance of transactions or the establishment of business relations without the physical presence ${ }^{4}$ of the client. Thus, the regulation is made in article 6/2 of law no. 9917, dated 19.5.2008 "On the Prevention of Money Laundering and Terrorist Financing", as amended. According to this provision, entities (financial institutions, banks, etc.) must implement specific procedures and take appropriate and effective measures to prevent the risk associated with transactions ${ }^{5}$ or business relationships performed without the

\footnotetext{
1 Balla, R. (2008). Protection of Personal Data - a new challenge for the Albanian society. Journal Parliamentary Law and Legal Policies. Tirane, Albania. no. 42 pg. 21-40.

2 Balla, R. (2017) The Fight Against Money Laundering and Terrorist Financing. International Conference, Globalization, Vision for Sustainable Future of the Mediterranean University of Tirana, Albania.

${ }^{3}$ Amendments of Law no. 9917, dated 19.5.2008 "On the Prevention of Money Laundering and Terrorist Financing", published in the Official Journal no. 99, year 2019, p. 7179.

4 Balla, R. (2018) Combating Money Laundering and Terrorism Financing in Albania. Amendments to the Legislation on AML/CTF. SEE/EU Cluster of Excellence in European and International Law. Series of Papers Volume 4, Saarland University, Germany. p.121

${ }^{5}$ Hartley, I. (2008) Corporate Crime. Contemporary World Issues. p. 87.
} 
physical presence of the client. From a legal point of view, we can say that this provision contains a very broad definition of "appropriate and effective measures". This is a formulation that leaves room for different interpretations, as for different subjects of the law, different measures can be defined as 'appropriate and effective measures". Therefore, DPML should definitely instruct the subjects by identifying some appropriate measures as "appropriate measures".

The improvement of this provision is very progressive because the previous stipulation, has been the main obstacle to the performance of digital financial services. However, we can say that even after a long time has passed since the entry into force of this provision, its practical implementation has not yet begun. Currently, no financial institution provides financial services entirely online, even though, it is already allowed the performance of operations remotely, without the physical presence of the client. DPML should work harder to enable financial institutions to perform their services effectively, digitally, completely without the physical presence of customers. By preparing instructions and guides with clear recommendations on the possibility of effective implementation of this legal provision.

The provisions of the law on the prevention of money laundering have indicated the need of amendments of other regulations to have harmonized and unified regulations. By imposing respective amendments in order to unify the regulatory framework, by reflecting them in the Regulation ${ }^{1}$ of the Supervisory Council of the Bank of Albania no. $44 / 2009$ "On the prevention of money laundering and terrorist financing" as amended. Thus, based on its point 6 , it is foreseen that the subjects can enter into business relations or even opening bank accounts without the physical presence of the client.

Another element that enables and facilitates the performance of online financial services is the definition of the term virtual tool. This term is defined for the first time in the Albanian legislation with the following explanation: "Virtual tool" is a digital representation of a value that can be traded or transferred in digital form, and that can be used for payment or investment purposes, thus including but not limited to cryptocurrencies. This definition does not include digital reflections of officially recognized currencies such as those issued by central banks, securities and other financial instruments provided for by applicable law.

A novelty in Albanian legislation is the definition of the term third party. The law gives, the following definition for this: "Third Party", means a subject supervised by the competent authorities, necessarily registered in Albania, in one of the member states of the European Union or third countries, provided that they meet the conditions as follows: a) to be regulated by a special law and to be obliged to be

\footnotetext{
${ }^{1}$ Regulation of the Supervisory Council of the Bank of Albania no. 44/2009 "On the Prevention of Money Laundering and Terrorist Financing" as amended, published in the Official Journal, the latest amendments dated 24.12.2019.
} 
register in the respective country; b) to be registered in the Republic of Albania, the member states of the European Union or in a third country, provided that they apply the same or higher requirements as those established by this law for proper and expanded vigilance, identifying the client and the beneficiary owner, storing information, and to be supervised by the competent authorities for compliance with money laundering and / or terrorist financing prevention issues. This definition constitutes a relief for all entities that by law intend to rely on third parties. The process of relying on third party is very important for the functioning of the performance of digital financial transactions, especially for non-bank financial institutions. However, even if these institutions can finalize the approval of the transaction or loan, the support of third parties must be provided to enable the disbursement of the credit in the bank account of the client. Thus, Article 6/1 of the law defines the procedure and criteria for relying on third parties.

\section{II.2- Central Bank of Albania's Regulation}

At the same time, another obstacle for the digitalization of financial services have been the provisions of Regulation ${ }^{1}$ no. 28 dated 30.03.2005 "On the supervision of banking transactions electronically", as amended. Thus, according to Article 5 "Prohibitions", banks are not allowed to open e-banking accounts without the physical presence of the customer in the bank. Meanwhile, with the amendments of the Regulation in December 2019, this article has been repealed. Similarly, according to Article 6 of the Regulation, banks can perform e-banking only after verification of the fulfillment of the conditions and criteria by the Bank of Albania. So, through these amendments above mentioned, it is possible to allow online transactions or e-banking without the physical presence of the client.

Based on the Decision of the Bank of Albania no. 59 dated 29.08.2008 On the Approval of the Regulation" "On Transparency for Banking and Financial Products and Services", as amended, it is stipulated that electronic means of communication can be used to build business relationships with clients. So even this regulation enables the facilitation of the performance of digital financial services.

\section{II.3- Other Legal Provisions}

Another very important aspect of the online process is the electronic agreement. Currently, the official electronic signature has started to be used in Albania. But this

\footnotetext{
${ }^{1}$ Regulation of the Supervisory Council of the Bank of Albania no. 28 dated 30.03.2005 "On the supervision of banking transactions electronically", as amended ', published in the Official Journal, the latest amendments dated 18.12.2019.

https://www.bankofalbania.org/Mbikeqyrja/Kuadri_Rregullativ_Mbikeqyres/Rregullore_te_mbikeqyrj es/Rregullore_Nr_28_Per_mbikeqyrjen_e_transaksioneve_bankare_ne_rruge_elektronike.html visited on 03.06.2020.

2 Regulation of the Supervisory Council of the Bank of Albania no. 59 dated 29.08.2008 "On

Transparency for Banking and Financial Products and Services", as amended, published in the Official Journal.
} 
signature is known and works only for the official signatures of public servants who provide online services through official websites such as e-Albania. Whereas, for private legal entities that want to use the electronic signature, they can proceed with a request to the NAIS ${ }^{1}$, as the competent institution for issuing certificates for electronic identification and trusted services. Currently, electronic agreement is not used in the market, although the legal framework provides and has created the ground for their use. Technological developments and improvement of services offered to the market and customer imposes the implementation of electronic agreement, therefore in this regard should be established by a regulation or legal binding act the implementation of agreement with electronic signature by individuals.

The online process facilitates distance identification of customers, in accordance with the above legal basis, mainly the law on prevention of money laundering which follows the best practices of the European Union and enables safe processing of personal data ${ }^{2}$ of customers in accordance with the law on personal data protection, as well as Management Information Security Standards.

Despite the regulatory framework, there are some issues on the recognition and acceptance of electronic documents. Currently, commercial banks are reluctant to recognize electronic documents, for example, it is evident that the electronic extracts of legal entities are not accepted as a document in electronic format. The electronic document is processed by the official website of the National Business Register and stamped with an electronic stamp certified by the public authority. So, there is no reason not to ensure the use of these documents in the context of digitalization. Likewise, the courts have begun accepting electronic documents on paper, but the practice is not unified and there are judges who show resistance on accepting electronic documents. This practice should be changed and unified where all courts in the Republic of Albania uniformly must accept the electronic agreement without resistance and without questioning the authenticity of the document.

In this regard, appropriate infrastructure should be created in institutions to receive and accept the document electronically. According to Article 10 of Law 10273 / 29.04.2010 "On the Electronic Document" and the Instruction 1/31.12.2012 "On the Certificate of Copy in Letter of the Electronic Document from Public Institutions" requires the unifying stamp in the paper copy of the electronic document from the issuing institution of the document or by the public notary, encouraging public and private institutions not to use the electronic service. In our estimation, the paper copy of the electronic document should not bear any kind of stamp, as this would lose the

\footnotetext{
1 The National Agency for the Information Society, which is the competent institution for the recognition and certification of electronic signatures, in accordance with law no. 9880 dated 25.02.2008 "On Electronic Signature", as amended ", as well as law no. 107/2015 "On Electronic Identification and Trusted Services", as amended;

2 Law no. 9887 dated 10.03.2008 "On the protection of personal data in the Republic of Albania' amended, published in the Official Journal.
} 
purpose of the electronic document and the speed of service leading even to financial costs. Anyone who modifies the content of the paper copy of the electronic document must be subject to criminal legal provisions of the illegal interference ${ }^{1}$ with the forgery of the document.

Identity cards are not equipped with "readers" to perform electronic identification and as a result electronic identification is not widely used. In order to protect the financial system as a whole from fraud and to solve once and for all the problem of fraud (persons whom sign for other persons in agreements) a wider campaign should be undertaken for the implementation of readers in identification documents.

Similarly, taking into consideration the law on consumer protection, according to which loans for amounts less than 30,000 ALL and loans in the nature of overdrafts are excluded from the scope of its implementation (so no extended contractual conditions are required), regarding the regulation of the Bank of Albania on consumer and mortgage loans and regarding the requirements of the legislation for the prevention of money laundering, we estimate that for these types of loans should be implemented and sanctioned by more mitigating measures in terms of developing a simplified diligence to the client and contractual terms. In this regard, reviewing the necessary guidelines in the regulation of the Bank of Albania for consumer and mortgage loans would facilitate digitalization process.

Another important aspect of the online process is the certification of electronic programs that will enable electronic identification entirely in the electronic environment, as trusted services that truly provide electronic identification based on the established algorithms. These criteria are provided by law2 no. 107/2015 "On Electronic Identification and Trusted Services". Based on Article 34 "Acceptance and use of foreign products" is stipulated that trusted products, created by qualified service providers trusted outside the Republic of Albania, will be recognized only through the relevant agreements signed by the Republic of Albania with other countries. For Qualified Trustees of the Trusted Service, who operate in the Member States of the European Union and are accredited by the relevant supervisory authority, the trustworthy credentials and services issued by them shall have the same legal validity and probative value as those issued by a Qualified Trustee of the Trusted Service, operating in the Republic of Albania.

\section{International, European Incentives}

\section{III-1 European Incentives}

European initiatives on creating a suitable environment for making payments, transactions and other online services have started earlier than in Albania. Building

\footnotetext{
1 Gilbert/Pontell. (2007), International Handbook of White-Collar Corporate Crime. p. 67.

2 Law no. 107/2015 "On Electronic Identification and Trusted Services", amended published in the Official Journal.
} 
trust on the online environment is essential for economic and social development. Consumers need to feel safe and legal assurance is an essential element not only in building the online process but in building all other business relationships. Lack of trust, especially due to a lack of perception of legal assurance, makes consumers, businesses, and public authorities reluctant to perform transactions electronically and adopt new services.

Thus, the European Parliament and the Council of Europe have adopted Regulation ${ }^{1}$ no. 910/2014 of the European Parliament and the Council on 23 July 2014, On Electronic Identification and Trust Services for Electronic Transactions in the Internal Market and the Amendment of Directive 1999/93. This regulation aims to strengthen confidence in electronic transactions in the domestic market by providing a common foundation for secure electronic interaction between citizens, businesses and public authorities, thus increasing the effectiveness of public and private online services, ebusiness and e-commerce in the whole common European jurisdiction. In its conclusions of 27 May 2011, the Council of Europe invited the Commission to contribute to the single digital market by creating appropriate conditions for the mutual recognition of key providers across borders, such as electronic identification, electronic documents, electronic signatures and delivery of electronic services. and for interoperable e-government services throughout the European Union.

The European Parliament, in its resolution of 21 September 2010 on the completion of the domestic market with e-commerce, stressed the importance of the security of electronic services, especially electronic signatures, and the need to create an important public infrastructure at the pan-European level and called on the Commission to establish a platform for European evaluation authorities, to ensure cross-border interaction of electronic signatures and to increase the security of transactions made by using the internet platform.

Additionally, another important act in this process is the regulation ${ }^{2}$ of the payment service. Payment services are regulated by the provisions of (PSD II) - Directive ${ }^{3}$ (EU) 2015/2366 which entered into force on 12 January 2016 and its application has started since 13 January 2018. One of the objectives of PSD II is to ensure the security of electronic payments and to reduce, to the maximum extent possible, the risk of

\footnotetext{
${ }^{1}$ Regulation (EU) no. 910/2014 of the European Parliament and of the Council of 23 July 2014, On Electronic Identification and Trust Services for Electronic Transactions in the Internal Market and Repeal of Directive 1999/93, published in the Official Journal of Europe OJ L 257, 28.8.2014.

2 Regulation of the Delegated Commission of (EU) 2018/389 of 27 November 2017 supplementing Directive (EU) 2015/2366 of the European Parliament and of the Council concerning technical regulatory standards for strong client authentication and open and secure standards of communication (OJ L 69, 13.3.2018, p.23).

3 Directive (EU) 2015/2366 of the European Parliament and of the Council of 25 November 2015 on payment services in the internal market, amending Directives 2002/65/EC, 2009/110/EC and 2013/36/EU and Regulation (EU) No 1093/2010, and repealing Directive 2007/64/EC. https://eur-lex.europa.eu/legal-content/EN/TXT/?uri=CELEX\%3A32015L2366
} 
fraud (recital 95). Based on the Recital 7 of PSD II it is stated that "security risks associated with electronic payments are increased". Meanwhile as per Recital 95 it is further stated that "the security of electronic payments is essential to ensure the protection of users and the development of a healthy environment for e-commerce". This Directive provides a strong legal basis for further and better development of the domestic market for electronic payments within the European Union. It sets out comprehensive rules for the purpose of making international payments (within the EU) simpler, more efficient, and safer as they are made within a single country. This Directive aims to open the payment market to new participants, moving more towards competition, alternatives, and better prices for consumers. It also provides a legal platform for a single euro payment area.

The Directive aims to improve existing European Union rules on electronic payments. It considers the development of innovative payment services, such as mobile or online payments. In particular, the directive sets out rules relating to strict security requirements, electronic payments and protection of consumer financial data, guaranteeing safe verification and reduction of fraud risk, transparency of conditions and information requirements for payment services the rights and obligations of users and providers of payment services.

The Directive is complemented by EU Regulation 2015/751 which sets out a limit on exchange rates between banks for card-based transactions. It is expected that from the entry into force of the Directive and the Regulation, the costs of traders in accepting debit or consumer credit cards will be reduced. This process will lead to the formalization of payments and if it works even in the Albanian payment market, it will undoubtedly contribute to the formalization of the economy in general. The Directive creates a clear set of rules to be applied to new and existing providers of innovative payment services. These rules aim to ensure that providers of the financial services can compete on an equal terms and conditions, leading to greater efficiency and transparency of payment services, while strengthening consumer confidence in a harmonized market.

According to the Directive, consumer rights have been improved, including the reduction of liability for unauthorized payments by Eur $€ 150-€ 50$, the right to unconditional repayment for direct debits in Euros for a period of 8 weeks. It also provides customers with the removal of fees for the use of debit or credit cards. In order to help consumers, the European Commission prepared a brochure from the beginning of 2018 listing and explaining consumer rights under the European Directive and the law as a whole. The role of the European Bank Authority to develop a publicly accessible central register of all authorized payment institutions, which will be updated by national authorities, has also been enforced. Its role in assisting in resolving disputes between national authorities has been strengthened. The European Central Bank will develop regulatory technical standards to strengthen customer authentication verification and develop criteria for secure communication 
channels, which will be met and implemented by all service providers. It will also develop regulatory technical standards on cooperation and information exchange between supervisory authorities.

In this context, in order to enable the most effective implementation of the Directive, the European Commission has adopted several Regulations, such as Regulation (EU) 2017/2055 On Determining Technical Standards for Cooperation and Information Exchange between Competent Authorities regarding the Exercise of the Right to Freedom of Establishing Payment Services Institutions. Regulation (EU) 2018/389 On the Determination of Technical Standards for Strong Customer Verification and Standards for Safe and Common Communication. Regulation (EU) 2019/410 Defining the Implementation of Technical Standards for the Purpose of Detailed and Structured Information Notification in the Field of Payment Service by the Competent Authorities to the European Central Bank. Regulation (EU) 2019/411 On the Determination of Technical Standards for the Development of Technical Requirements, Operations and Maintenance of the Central Electronic Register within the Payment Service Area and On Access to Information Contained in it.

It should be noted that in this initiative, so the performance of online payment services, the Baltic ${ }^{1}$ countries are the vanguard in the enterprises that have done both institutionally and legally. We can also say that there are similarities between the Baltic states, such as Lithuania, Latvia and Estonia, and the Balkan countries, both in terms of GDP growth and population growth. Thus, the development of a favorable regulatory and supervisory ecosystem for FinTech ${ }^{2}$ as well as the promotion of innovation in the financial system is one of the strategic directions of the Bank of Lithuania. Together with other state authorities, the Bank of Lithuania aims to create a FinTech-friendly environment that will attract new companies and encourage them to create new products in the country.

The Baltics are leading the digitalization of financial services in Europe. In Latvia, for example, the first eurozone immediate payment systems $(24 / 7 / 365)$ have been launched in line with the Single European Payments Area (SEPA) project. It is also experimenting with innovative data sharing services from the client file (KYC) to all participants in the financial sector, using biometric data to identify the client. On October 2018, Lithuania 3 launched the regulatory "sandbox", which allows market participants to execute innovative FinTech products or business models in a virtual environment with real customers, under the direction and supervision of the Lithuanian Bank. The regulatory box is only open for financial services, products or

\footnotetext{
${ }^{1}$ Based on the proceedings of the International Conference on Digitalization of Financial Services organized in October 2019, in Skopje, Northern Macedonia, the "special guests" were delegates from the Central Banks, the Ministries of Finance and other supervisory authorities of the three Baltic states, namely Lithuania, Latvia and Estonia.

2 FinTech is the abbreviation of the word's financial technology in English.

https://www.lb.lt/en/fintech-and-innovation visited on 01.06.2020.

${ }^{3}$ Lithuania sandbox project https://www.lb.lt/en/regulatory-sandbox visited on 01.06.2020.
} 
business models that are new to the Lithuanian market. Adoption of financial innovation will bring identifiable benefits to society, e.g. more appropriate, safer, and cheaper financial services, or otherwise they will contribute to the sustainable development of the financial market. The necessity to test financial innovations in a controlled environment is objectively justified, while the testing itself can contribute to the implementation of the innovation in question.

Estonia has digitized many aspects of the lives of its citizens, from voting routines to pharmacy prescriptions to driving licenses. So, it's no wonder that Estonian school children are stimulated to learn about financial education using bank applications designed specifically for them.

\section{III-2 FATF1 Guidelines}

Most of states have adopted 40 Task Force Recommendations ${ }^{2}$ on Financial Action on Money Laundering, and Terrorist Financing. These recommendations include criminalizing Money Laundering and Terrorist Financing, freezing and seizing terrorist financing, preventing measures against Money Laundering and Terrorist Financing for financial institutions, intelligence units and international cooperation. FATF recommendations set international standards for preventing and combating money laundering ${ }^{3}$ and terrorist financing. In any financial transaction to get to know the customer it is essential to ensure that the funds involved are not linked to crime and terrorism. However, in a digital context traditional verification tools are not included. The FATF has approved guidelines ${ }^{4}$ that will help governments, financial institutions, virtual asset service providers and other regulatory units determine whether a digital ID is suitable for customer verification. Digital ID validity can be made easier and cheaper and it will be safer to identify individuals in the financial sector. This will also help monitor requirements and minimize human vulnerabilities in control measures. Digital ID systems are evolving very fast. To determine if a digital ID is valid, governments, financial institutions, and other stakeholders need to understand the security level of the technological system, architecture, and digital ID governance. Depending on the level of security, it is determined whether the appropriate independent reliability in light of the potential risks used may or may not facilitate illegal financing.

\footnotetext{
${ }^{1}$ Financial Action Task Force - financial action unit on money laundering prevention.

2 All FATF Recommendations which are 40 and 9 Special Recommendations on Terrorist Financing constitute a comprehensive package of measures for an effective legal and institutional regime against money laundering and terrorist financing. The United Nations Resolution 1617 (2005) of the Security Council and the Resolution Action Plan 60/288 of the United Nations General Assembly (20 September 2006) reinforce the importance of implementing these Recommendations.

3 Gordon, I. (2011) Losing the War Against Dirty Money. Duke Journal of Comparative and International Law p. 503.

${ }^{4}$ FATF March 2020 Guidelines http://www.fatf-gafi.org/media/fatf/documents/reports/Digital-ID-inbrief.pdf visited on 08.06.2020.
} 
With over 1.7 billion adults worldwide who do not process with banks and $26 \%$ of them report deficiencies in documentation as an obstacle to accessing the banking system, digital ID offers another significant benefit. A strong digital ID can allow individuals without a traditional identification to have in the other hand a strong form of identification in order to access financial services and improve financial inclusion. The number of digital transactions has increased by approximately 13\% per year. From 2022 it is estimated that it will reach $60 \%$ of global GDP which will be digitalized. There is a huge demand from the private sector to be able to confidently identify people in the digital environment. Currently, there are no universally accepted international standards for digital ID development. The guideline sets a number of standards as a framework for guaranteeing digital IDs, especially those in force in the United States and the European Union, to establish links between the highly technological world of digital IDs and policy development to combat money laundering and financing of terrorism. The FATF sought comments on its guidance that could clarify how digital identity systems can be used to verify clients through a public consultation.

The guideline clarifies that not every face-to-face identification of the client and transactions relying on reliable independent systems and digital identification with appropriate risk mitigation measures may present a standard level of risk or may even be low risk.

\section{Conclusion}

Based on what is elaborated above, regarding the inclusion of the use of financial technology for payment services, we conclude that the Albanian market will undoubtedly welcome and use it as a suitable tool for performing transactions faster, better and at no cost. A very important role in this process undoubtedly will be played by AML agency. Based on the conclusion it is recommended to the AML agency that should instruct in a simplified manner on the appropriate measures to be taken by financial entities that want to embrace this innovation in performing payments.

Financial institutions in the Albanian market must take initiatives to enable the performance of these online financial services in a digital environment. However, compared to the bureaucracies and administrative barriers of banks, they will greatly facilitate the development of transactions more quickly and efficiently. It is recommended to the financial institution that they must carry out detailed risk-based analysis, for the process of distance identification of the client which must be carried out in compliance with the Law on Prevention of Money Laundering and at the same time with the Law on Data Protection. Since distance identification as a process involves biometric data of individuals, the processing of personal data may jeopardize their privacy.

Undoubtedly, the supervisory role is also very important in this process. Currently, the Central Bank of Albania has not made public any of its initiatives regarding the 
implementation of Directive (EU) 2015/2366 on the facilitation of the performance of the payment service, as well as the Regulations for its implementation. Therefor it is recommended the development of an appropriate, regulatory, and supervisory ecosystem for financial technology. Based on the Bank of Albania's Regulation on Prevention of Money Laundering it is stipulated that the online process must be evaluated by financial entities as high risk and on those clients will be implemented enhanced vigilance. But the FATF's guideline clarifies that not every face-to-face identification of the client and transactions relying on reliable independent systems and digital identification with appropriate risk mitigation measures may present a standard level of risk or may even be low risk. So, it is recommended to the Bank of Albania to change the level of risk from high to low risk on online process clients. The promotion of innovation in the financial system, should be the direction of the Central Bank of Albania's strategy. Adoption of financial innovation will bring identifiable benefits to society, more appropriate, safer and cheaper financial services, or in other words will contribute to the sustainable development of the financial market.

\section{Bibliography}

[1] Study conducted by the organization IDRA published by the Albanian Microfinance Association at Bankieri Magazine, no.26, Tirana, April 2020.

[2] Balla, R. (2008). Protection of Personal Data - a new challenge for the Albanian society. Journal Parliamentary Law and Legal Policies. Tirane, Albania. no. 42.

[3] Shegan, A. (2010), La lutte contre le terrorisme: étude de droit comparé (droit français, droit albanais) et de droit pénal international, Tirane, Albania..

[4] Balla, R. (2017) The Fight Against Money Laundering and Terrorist Financing. International Conference, Globalization, Vision for Sustainable Future of the Mediterranean University of Tirana, Albania.

[5] Hartley, I. (2008) Corporate Crime. Contemporary World Issues.

[6] Gordon, Losing the War Against Dirty Money, Duke Journal of Comparative and International Law 2011, p. 503.

[7] Gilbert/Pontell. (2007), International Handbook of White-Collar Corporate Crime.

[8] The proceedings of the International Conference on Digitalization of Financial Services organized in October 2019, in Skopje, Northern Macedonia.

[9] Balla, R. (2018) Combating Money Laundering and Terrorism Financing in Albania. Amendments to the Legislation on AML/CTF. SEE/EU Cluster of Excellence in European and International Law. Series of Papers Volume 4, Saarland University, Germany

[10] Lithuania sandbox project.

\section{European and International Legal Acts}

[1] Directive (EU) 2015/2366 of the European Parliament and of the Council of 25 November 2015 on payment services in the internal market. 
[2] Regulation (EU) no. 910/2014 of the European Parliament and of the Council of 23 July 2014, On Electronic Identification and Trust Services for Electronic Transactions in the Internal Market and Repeal of Directive 1999/93, published in the Official Journal of Europe OJ L 257, 28.8.2014.

[3] Regulation of the Delegated Commission of (EU) 2018/389 of 27 November 2017 supplementing Directive (EU) 2015/2366 of the European Parliament and of the Council concerning technical regulatory standards for strong client authentication and open and secure standards of communication (OJ L 69, 13.3.2018, p.23).

[4] FATF March 2020 Guidelines.

\section{Legal Acts}

[1] Amendments of Law no. 9917, dated 19.5.2008 "On the Prevention of Money Laundering and Terrorist Financing", published in the Official Journal no. 99, year 2019, p. 7179.

[2] Law no. 9880 dated 25.02.2008 "On Electronic Signature", as amended.

[3] Law no. 107/2015 "On Electronic Identification and Trusted Services", as amended.

[4] Law no. 9887 dated 10.03.2008 "On the protection of personal data in the Republic of Albania' amended, published at the Official Journal.

[5] Regulation of the Supervisory Council of the Bank of Albania no. 44/2009 "On the Prevention of Money Laundering and Terrorist Financing" as amended, published in the Official Journal, the latest amendments dated 24.12.2019.

[6] Regulation of the Supervisory Council of the Bank of Albania no. 28 dated 30.03.2005 "On the supervision of banking transactions electronically", as amended ', published in the Official Journal, the latest amendments dated 18.12.2019.

[7] Regulation of the Supervisory Council of the Bank of Albania no. 59 dated 29.08.2008 "On Transparency for Banking and Financial Products and Services", as amended, published in the Official Journal.

\section{Internet web page:}

[1] https://eur-lex.europa.eu/legal-content/EN/LSU/?uri=CELEX:32015L2366

[2] https://www.bankofalbania.org/Mbikeqyrja/Kuadri_Rregullativ_Mbikeqyre s/Rregullore_te_mbikeqyrjes/Rregullore_Nr_28_Per_mbikeqyrjen_e_transak sioneve_bankare_ne_rruge_elektronike.html.

[3] https://eur-lex.europa.eu/legalcontent/EN/TXT/?uri=uriserv\%3AOJ.L_.2014.257.01.0073.01.ENG

[4] https://eur-lex.europa.eu/summary/glossary/implementing_acts.html

[5] https://www.lb.lt/en/fintech-and-innovation

[6] http://www.fatf-gafi.org/media/fatf/documents/reports/Digital-ID-inbrief.pdf 
